\title{
Adaptation strategies and referencing trial of Scots and black pine populations subjected to heavy metal pollution
}

\author{
Ewa Chudzińska • Jean B. Diatta • \\ Aleksandra Wojnicka-Póltorak
}

Received: 30 April 2013 / Accepted: 16 August 2013/Published online: 17 September 2013

(C) The Author(s) 2013. This article is published with open access at Springerlink.com

\begin{abstract}
The impact of industrial heavy metal pollution on Scots pine (Pinus sylvestris L.) and black pine (Pinus nigra Arn.) populations was investigated. Sampled pine stands, which were located in Upper Silesia (southern Poland) in an area strongly polluted by heavy metals, consisted of resistant and sensitive trees. To evaluate the adaptation process, genetic structure and diversity was tested using isozyme analysis. Higher levels of $\mathrm{Zn}, \mathrm{Pb}, \mathrm{Cd}$ and $\mathrm{Cu}$ were detected in needles of sensitive trees compared with resistant ones. With respect to morphology, Scots pines were more distinctly impaired than black pines. Although black pines had lower heavy metal concentrations, levels in 1-year-old needles, other than $\mathrm{Cu}$, significantly exceeded "reference plant" values (Markert 1994). In both species, resistant trees demonstrated a lower degree of genetic variation than metal-sensitive trees with respect to some enzyme loci (SHDH A, PGI, PGM, MDH C and DIA). This observation was corroborated in sensitive trees by the smaller number of identified alleles and alleles per locus, absence of private alleles and significant excess of homozygotes in relation to expected Hardy-Weinberg equilibrium values. Assuming that only resistant trees of both species survive under conditions of prolonged soil contamination, the observed genetic structure implies that remaining populations will be depleted of some alleles of unknown
\end{abstract}

Responsible editor: Elena Maestri

E. Chudzińska · A. Wojnicka-Półtorak

Institute of Experimental Biology, Department of Genetics, Adam

Mickiewicz University, ul. Umultowska 89, 61-614 Poznań, Poland

E. Chudzińska

e-mail: evpell@amu.edu.pl

\section{J. B. Diatta $(\bowtie)$}

Department of Agricultural Chemistry and Environmental

Biogeochemistry, Poznan University of Life Sciences, ul. Wojska

Polskiego 71F, 60-625 Poznań, Poland

e-mail: Jeandiatta63@yahoo.com adaptive value to future selection pressures. Genetic changes induced by heavy metals suggest an important role for specific enzymes-FEST, SHDH A and B, GOT B and PGI-in the adaptation process. Our results may serve as a basis for selection and propagation of individuals appropriate for recultivation of areas chemically degraded by industrial activity.

Keywords Genetic variation · Heavy metal · Enzymes · Pinus nigra $\cdot$ Pinus sylvestris $\cdot$ Reference plant

\section{Introduction}

The influence of heavy metals on plants growing in strongly polluted areas has been extensively discussed in regard to many different aspects (Patra et al. 2004; Benavides et al. 2005; Pavlik et al. 2012; Acquaviva et al. 2012). Beginning with the first observation of enhanced tolerance to heavy metals in certain plants (Prat 1934), the question of the genetic background of this tolerance has been repeatedly raised, especially with respect to potential selective evolution towards genotypes exhibiting higher resistance to this type of environmental stress (Dubois et al. 2003; Prus-Głowacki et al. 2006; $\mathrm{Au}$ 2012). Variation in coniferous tree populations in industrial areas has primarily been studied by comparing their genetic structures to populations from uncontaminated regions (Serbula et al. 2012; Korshikov et al. 2005). Studies comparing the genetic structure of species subjected to severe heavy metal contamination within the same area are still scarce; furthermore, most such studies restrict their analyses to the genetic structure of impaired trees without considering possible readaptation processes and future plant reintroduction.

In the genus Pinus, two species are often used for contamination biomonitoring: Pinus sylvestris L. (Scots pine) and Pinus nigra Arn. (black pine). Scots pine, the main forestforming species in Europe, is sensitive to several industrial 
pollutants, including heavy metals (Miceta and Murin 1998; Rautio et al. 1998; Nieminen et al. 2004). Trees of this species growing under severe industrial emissions exhibit abnormal dwarfed conformations as a result of atrophy affecting shoots and growth inhibition. Such trees typically have only 2 -yearold needles, which are shorter than needles of trees in lowpollution areas (Lamppu and Huttunen 2003; Chudzińska and Urbaniak 2008). Black pine is more tolerant to heavy metal pollution than Scots pine (Oleksyn et al. 1987; Pavlik et al. 2012). Black pines seriously endangered by industrial emissions display standard conformations and usually retain their 3 -year-old needles.

Extinction caused by industrial pollution, predominantly accumulation of high amounts of toxic metals in soil, can be observed in pine forests even several decades after elimination of emissions. One such example is the forest investigated in this study, which is located in Upper Silesia (southern Poland) in an area strongly polluted by heavy metals. In this zone, concentrations of metals such as copper, lead, zinc and cadmium are typically much higher than normal Polish background levels (Diatta et al. 2008). This is a side effect of local zinc smelter activity, which emitted considerable metallurgical dust until the end of the 1990s (Prus-Głowacki et al. 2006).

In plant populations growing under such conditions, the damaging effect of pollution is a stress-selective factor leading to the death of less-resistant specimens. This in turn induces changes in genetic diversity, such as the proportion of polymorphic loci, number of alleles per locus, effective number of alleles and expected heterozygosity, which can be determined based on allozyme studies. Some tree species exhibit an increased number of heterozygous alleles under stress conditions caused by pollution, while others do not. In studies of $P$. sylvestris growing in areas surrounding operating metallurgical plants, Korshikov et al. (2002) reported a decrease in parameters such as the number of genotypes, alleles per locus and observed and expected heterozygosity. When Longauer et al. (2001) examined Norway spruce, European beech and European silver fir from different contaminated regions, they found that each of these species was characterised by heavymetal-induced individual genetic variation.

Heterozygosity is often used as a genetic indicator of tree fitness (Savolainen and Hedrick 1995; Hanson and Westerberg 2002; Schaberg et al. 2008). A positive correlation between heterozygosity and fitness has been demonstrated, based on tree growth rate, in aspen ( $\mathrm{Li}$ et al. 1998), Castanea dentata (Stilwell et al. 2003) and pine (Pinus rigida, Pinus taeda, Pinus attenuata and Pinus jeffreyi) (Ledig et al. 1983; Staszak et al. 2007; Schaberg et al. 2008). On the other hand, analyses have failed to show this type of correlation in Pinus ponderosa (Knowles and Grant 1981) or P. sylvestris (Savolainen and Hedrick 1995; Puglisi et al. 1999). While acknowledging the potential advantage of heterozygote vitality, a number of papers (Hanson and Westerberg 2002;
Hanson and Werterberg 2008; Schaberg et al. 2008) have pointed out that in small populations or in populations under strong selection, a positive fitness-heterozygosity correlation can be caused by factors other than intrinsic heterozygote advantage.

Relationships observed in coniferous trees between genetic differentiation and vitality under heavy metal stress have not been completely elucidated. Certain tree species exhibit an increased number of heterozygous alleles under stress conditions caused by pollution, while others do not (Longauer et al. 2001; Korshikov et al. 2005). Prus-Głowacki et al. (2006) observed that the presence of heavy metals in soils, combined with $\mathrm{SO}_{2}$ air pollution, resulted in a potential reduction in genetic variation in P. sylvestris populations. Among seedlings with high survival rates, heterozygosity levels and numbers of alleles were reduced in relation to those in analysed initial populations. Such a situation is typically interpreted to be a consequence of adaptation processes (Prus-Glowacki and Godzik 1991; Bergman and Hosius 1996).

In this study, we examined whether higher tolerance to heavy metal soil contamination is linked to changes in population genetic structure of pines growing under strong habitat pressure using isozyme markers. We then assessed copper, zinc, lead and cadmium levels in soils and Scots and black pine needles affected by metallurgical activities. A "reference trial" was also conducted to evaluate the degree of contamination in the investigated pines.

\section{Materials and methods}

Pine species and sampling of plant material

The investigated species were $P$. sylvestris and $P$. nigra populations consisted of 35-40-year-old trees, which were highly variable in terms of health status. Trees in good condition and exhibiting no major signs of damage were growing adjacent to trees with dwarfed habits, considerable crown defoliation and needle discolouration (Prus-Głowacki et al. 2006).

Plant material (i.e. pine needles and dormant buds) was collected from Scots and black pine stands comprising 100 individuals divided into sensitive and resistant groups (50 individuals per group). Trees were growing in a strongly impacted area (Photo 1) located 500-1,000 m north-northeast of the local zinc smelter (Diatta et al. 2008, 2011). One-yearold needles and dormant buds were harvested from the middle third of the crown of randomly selected trees of both species.

Study area

The sampling area was located in the vicinity of the zinc

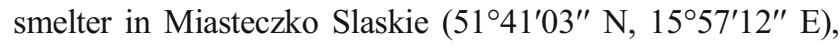




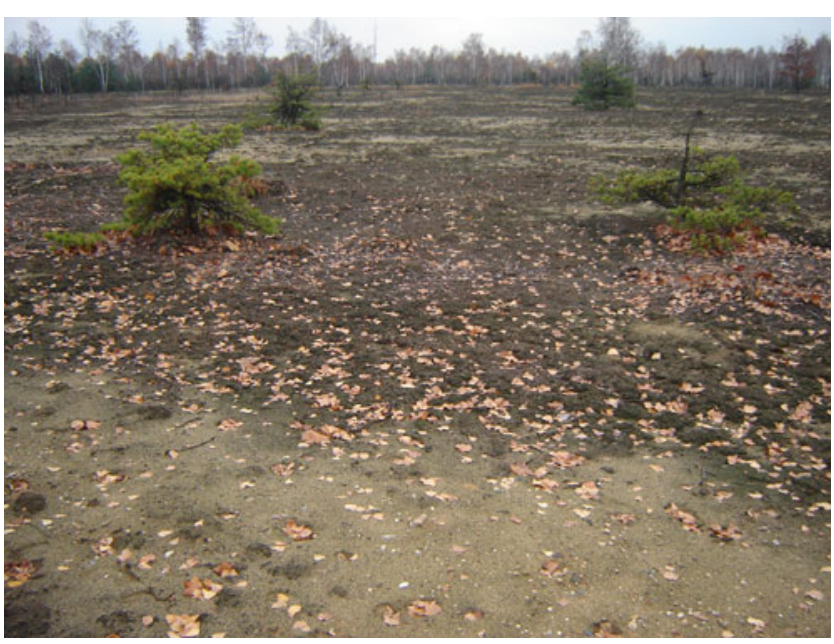

Photo 1 Study area with a view of single dwarf pines

Upper Silesia, Poland. Because prevailing winds are from the southwest (21.4\%) and west (18.7\%), pollution emitted by the zinc smelter has the greatest impact on areas to its northeast and east. Although heavy metal deposition has ceased, soils around the smelter are still contaminated (Prus-Głowacki et al. 2006; Diatta et al. 2008). In this region, degeneration of Scots and black pine stands is highly noticeable: with high defoliation rates, reduced growth and extensive needle damage, the trees stand out from surrounding forests (Photo 1).

Soil sampling and chemical analyses

Soils were sampled at four depths, 0-20, 20-40, 40-60 and 60-80 cm, following the design illustrated in Photo 2. This procedure was adopted to detect spatial trends in physical and chemical properties that might be responsible for heavy metal geochemical processes. Soil samples were subsequently dried at room temperature and passed through a 1-mm mesh sieve. Soil reaction $(\mathrm{pH})$ was determined potentiometrically in a slurry of 0.010 moles $\mathrm{CaCl}_{2} \mathrm{dm}^{-3}$ at a soil/solution ratio of

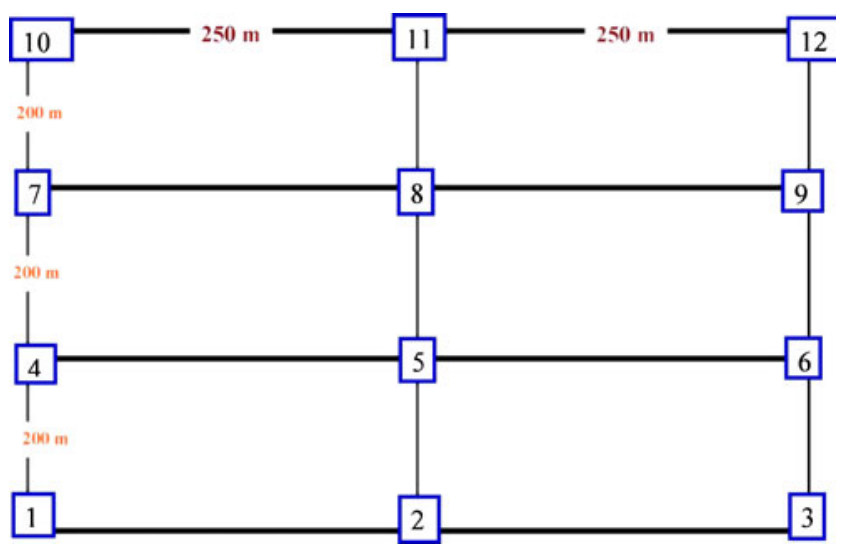

Photo 2 Sampling design. Numbers indicate the sampling sites with distance between them
1:5 (Polish Standard 1994). Cation exchange capacity (CEC) was assessed as the sum of alkaline $\left(\mathrm{Ca}^{2+}, \mathrm{Mg}^{2+}, \mathrm{K}^{+}\right.$and $\left.\mathrm{Na}^{+}\right)$ and acidic $\left(\mathrm{Al}^{3+}\right.$ and $\left.\mathrm{H}^{+}\right)$ions by applying 1 mole $\mathrm{CH}_{3} \mathrm{COONH}_{4} \mathrm{dm}^{-3}$, pH 7.0 and 1 mole $\mathrm{KCl} \mathrm{dm}{ }^{-3}$, respectively (Thomas 1982). Organic carbon matter $\left(\% \mathrm{C}_{\text {org. }} \times 1.724\right)$ was determined by oxidizing organic carbon bonds with $0.40 \mathrm{~N} \mathrm{~K}_{2} \mathrm{Cr}_{2} \mathrm{O}_{7} \mathrm{dm}^{-3}$ under acidic conditions, followed by titration with ferrous ammonium sulphate (Nelson and Sommers 1986).

Concentrations of aqua regia-soluble metals (i.e. $\mathrm{Cu}, \mathrm{Zn}$, $\mathrm{Pb}$ and $\mathrm{Cd}$ ) were determined according to the ISO 11466 (ISO 11466, 1995) procedure. An air-dried soil sample $(1.00 \pm 0.001 \mathrm{~g})$ was weighed into a glass beaker; $15 \mathrm{~cm}^{3}$ of aqua regia (1:3 concentrated nitric acid and hydrochloric acid) was added, and the beaker was heated under reflux for $2 \mathrm{~h}$ on a sand bath. Beaker contents were filtered through filter paper into a $15-\mathrm{cm}^{3}$ tube and filled to the mark with bidistilled water. Concentrations of heavy metals soluble in aqua regia were determined by atomic absorption spectrometry (AAS; Varian 250 Spectra plus) and considered as total metal content. Relative standard deviation (RSD) was calculated from pooled data for applied methods. In the precision test, the average RSD $\%$ of analysed soil samples for all metals ranged from 0.97 to $7.55 \%$. The accuracy of chemical tests was determined using a reference material (code RTH 912, lot 9; LGC Promochem GmbH).

Forms of bioavailable metals (i.e. $\mathrm{Cu}, \mathrm{Zn}, \mathrm{Pb}$ and $\mathrm{Cd}$ ) were then extracted by applying $0.10 \mathrm{~mol} \mathrm{NaNO}_{3} \mathrm{dm}^{-3}$ (Gupta and Häni 1989; Gupta and Aten 1993). Briefly, $10.00 \pm 0.005 \mathrm{~g}$ of air-dried sample was weighed into $50 \mathrm{~cm}^{3}$ plastic test tubes and $20 \mathrm{~cm}^{3}$ of extractant added. The slurry was shaken for $2 \mathrm{~h}$ on a mechanical shaker and then filtered. Heavy metals were determined as described above. All soil chemical tests were performed in duplicate.

\section{Total $\mathrm{Cu}, \mathrm{Zn}, \mathrm{Pb}$ and $\mathrm{Cd}$ content in pine needles}

Prior to grinding, needle samples were dried at $50{ }^{\circ} \mathrm{C}$ for 3 days. A $0.250 \pm 0.001 \mathrm{~g}$ portion of ground needles was weighed into tubes and mineralised in concentrated $\mathrm{HNO}_{3}$ (MARS5 CEM Corporation). The digests were filtered and heavy metals were determined by the AAS method (Varian 250 Spectra plus). Analyses were performed in duplicate.

\section{Genetic analyses}

Trees were divided into health status categories based on standards criteria reported in the literature (Kurczyńska et al. 1998; Galibina and Terebova 2008) (Table 1). One-year-old needles and winter buds were collected from branches at a height of $1.5 \mathrm{~m}$ on the northeastern side of trees. Enzyme extracts were prepared from two to three buds per tree. Extraction, buffer systems and electrophoretic conditions 
Table 1 Categories of damage in trees from which samples were collected (Kurczyńska et al. 1998)

\begin{tabular}{llllll}
\hline Category & $\begin{array}{l}\text { Needle } \\
\text { discolouration }\end{array}$ & $\begin{array}{l}\text { Crown } \\
\text { defoliation }\end{array}$ & $\begin{array}{l}\text { Needle } \\
\text { damage }\end{array}$ & $\begin{array}{l}\text { Presence of } \\
\text { 2-year old } \\
\text { needles }\end{array}$ & $\begin{array}{l}\text { Seed } \\
\text { germinability }\end{array}$ \\
\hline Healthy (H) & $0-10$ & $0-25$ & $0-10$ & $>90$ & $>90$ \\
Resistant (R) & $>25$ & $26-60$ & $11-50$ & $30-90$ & $50-90$ \\
Sensitive (S) & $>60$ & $>60$ & $>51$ & $<30$ & $<50$ \\
\hline
\end{tabular}

were as described by Conkle et al. (1982) and Cheliak and Pitel (1984). Analysed enzyme systems are listed in Table 2 (Appendix).

\section{Data analysis}

Data were analysed using GenAlEx 6.3 population genetic software (Peakall and Smouse 2006) and Statistica for Windows (www.statsoft.com). Means of genetic parameters were tested using the Mann-Whitney $U$ test and analysis of variance to verify their statistical significance. To detect possible effects of selection, the Ewens-Watterson test for neutrality (1,000 permutations) (Manly 1985) was performed for each locus using PopGene software (Yeh et al. 1997) and by the coalescence-based simulation method of Vitalis et al. (2001) using DetSel 1.0 software. Null distributions were generated using the following parameters: population size before the split $N_{0}=50$ and 500; mutation rate $\mu=0.01,0$. 001 and 0.0001 ; ancestral population size $N_{\mathrm{c}}=500,5,000$ and 50,000; time since bottleneck $T_{0}=50,500$ and 5,000 and time since divergence $l=50$ and 500. The Ewens-Watterson test defines an expected distribution of data points based on a defined $P$ value (in this case, $P=\mathrm{q}-1=0.01$ ), with loci outside

Table 2 The analysed enzyme systems

\begin{tabular}{llll}
\hline Enzyme system & Symbol & EC number & $\begin{array}{l}\text { Number } \\
\text { of loci }\end{array}$ \\
\hline $\begin{array}{l}\text { Fluorescent esterase } \\
\text { Glutamate dehydrogenase }\end{array}$ & FEST & 3.1 .1 .1 & 1 \\
$\begin{array}{l}\text { Glutamate-oxaloacetate } \\
\text { transaminase }\end{array}$ & GOT & 1.4 .1 .2$. & 1 \\
$\begin{array}{l}\text { Malate dehydrogenase } \\
\text { Shikimate dehydrogenase }\end{array}$ & MDH & 1.1 .1 .37 & 2 \\
$\begin{array}{l}\text { 6-phosphogluconate } \\
\text { dehydrogenase }\end{array}$ & SHDH & 1.1 .1 .25 & 2 \\
NADH-dependent dehydrogenase & NDG & 1.1 .1 .49 & 1 \\
$\begin{array}{l}\text { Diaphorase } \\
\text { Phosphoglucomutase }\end{array}$ & DIA & 1.6 .5 .3 & 1 \\
Phosphoglucoisomerase & PGM & 2.7 .5 .4 .3$. & 1 \\
\hline
\end{tabular}

$E C$ the enzyme commission number of this expected region considered to be evidence for recent selection.

\section{Results}

Geochemical parameters and heavy metal content in the study area

The study area was characterised by exceptionally low effective cation exchange capacity (mean $\mathrm{CEC}_{\mathrm{e}}$ value $=2.83 \mathrm{cmol}_{(+)} \mathrm{kg}^{-1}$ ). The values of this parameter were related to the predominance of the sand fraction $\left(>820 \mathrm{~g} \mathrm{~kg}^{-1}\right)$, low organic matter content (9.77 $\left.\mathrm{g} \mathrm{kg}^{-1}\right)$ and very acid medium $\left(\mathrm{pH}_{\mathrm{CaCl} 2}=4.28\right)$. Under such conditions, heavy metals are barely retained by soil colloids and their mobility should therefore increase. Heavy metal content varied spatially and downward according to the following ranges: 46.5-579.4 $(\mathrm{Zn}), 23.7-660.7(\mathrm{~Pb}), 0.20-14.4(\mathrm{Cd})$ and $1.8-121.3 \mathrm{mg} \mathrm{kg}^{-1}(\mathrm{Cu})$ (Table 3). At a depth of 0-20 cm, mean values were $322.7 \pm 62.10(\mathrm{Zn}), 386.0 \pm 49.14(\mathrm{~Pb}), 4.79 \pm 1.94$ (Cd) and $39.6 \pm 9.44 \mathrm{mg} \mathrm{kg}^{-1}(\mathrm{Cu})$. The soil was strongly contaminated, with $\mathrm{Zn}, \mathrm{Pb}$ and $\mathrm{Cd}$ content significantly exceeding threshold values for forest soils (Directive of the Polish Ministry of the Environment: Dz. U. no. 165, 2002). An assessment of metal contamination based on geoaccumulation index $\left(I_{\mathrm{geo}}\right)$, contamination factor $\left(C_{\mathrm{f}}\right)$ and degree of contamination $\left(C_{\mathrm{deg}}\right)$ (Diatta et al. 2008) revealed the process of chemical degradation occurring in local soils.

Analysis of bioavailable metal forms (Gupta and Häni 1989) revealed that their concentrations decreased with depth; this trend was progressive in the case of $\mathrm{Zn}, \mathrm{Pb}$ and $\mathrm{Cd}$, but was less pronounced for $\mathrm{Cu}$ (Table 3). It should be noted that bioavailable levels of $\mathrm{Zn}$ and $\mathrm{Cd}$ significantly exceeded threshold values, i.e. ca. 140 -fold and 43 -fold, respectively, as was also observed for $\mathrm{Pb}$ (ca. 2-fold, but only at a depth of 0-20 cm).

$P$. sylvestris and $P$. nigra trees that are now approximately 35 years old have been exposed since germination to an extremely strong environmental contamination pressure. Consequently, needles collected from both pine species exhibited particularly elevated $\mathrm{Pb}, \mathrm{Zn}$ and $\mathrm{Cd}$ contents (and moderate levels of $\mathrm{Cu}$; Table 4) caused by high soil concentrations of these elements, even though emissions of metalcontaining dusts were halted in the 1990s. Higher concentrations 
Table 3 Total and bioavailable $\mathrm{Cd}, \mathrm{Cu}, \mathrm{Pb}$ and $\mathrm{Zn}$ contents in soils of the study area (means for four depths: $0-20 ; 20-40 ; 40-60$ and $60-80 \mathrm{~cm}$ and 12 sampling sites, see Photo 2)

${ }^{a}$ Geochemical Atlas PIG (Lis and Piaseczna 1995)

${ }^{\mathrm{b}}$ Directive of the Polish Minister of Environment (Dz.U. no. 165 2002)

${ }^{\mathrm{c}}$ Mean value with standard deviation

${ }^{\mathrm{d}}$ Gupta and Hani (1989)

\begin{tabular}{|c|c|c|c|c|c|c|}
\hline \multirow[t]{2}{*}{ Metal } & \multicolumn{4}{|c|}{ Mean total content according to depths $(\mathrm{cm})$} & \multirow{2}{*}{$\begin{array}{l}\text { Geochemical } \\
\text { background } \\
\text { in the study area }\end{array}$} & \multirow{2}{*}{$\begin{array}{l}\text { Threshold } \\
\text { values for } \\
\text { forest soils }\end{array}$} \\
\hline & $\begin{array}{l}0-20 \\
\left(\mathrm{mg} \mathrm{kg}^{-1}\right)\end{array}$ & $20-40$ & $40-60$ & $60-80$ & & \\
\hline $\mathrm{Cd}$ & $4.79^{\mathrm{c}} \pm 1.94$ & $0.82 \pm 0.47$ & $0.15 \pm 0.10$ & $0.08 \pm 0.05$ & $0.4-0.8$ & 0.4 \\
\hline $\mathrm{Cu}$ & $39.6 \pm 9.44$ & $30.7 \pm 4.95$ & $37.7 \pm 6.59$ & $28.7 \pm 3.91$ & $4-8$ & 15 \\
\hline $\mathrm{Pb}$ & $386.0 \pm 49.14$ & $114.6 \pm 28.12$ & $48.9 \pm 15.20$ & $32.1 \pm 7.14$ & $20-40$ & 10 \\
\hline \multirow[t]{2}{*}{$\mathrm{Zn}$} & $322.7 \pm 62.10$ & $172.8 \pm 37.14$ & $64.7 \pm 22.01$ & $42.9 \pm 10.61$ & $40-80$ & 30 \\
\hline & \multicolumn{4}{|c|}{ Mean content of bioavailable forms ( $\mathrm{mg} \mathrm{kg}^{-1}$ ) } & \multicolumn{2}{|c|}{ Threshold values $\left(\mathrm{mg} \mathrm{kg}^{-1}\right)^{\mathrm{d}}$} \\
\hline $\mathrm{Cd}$ & $1.28 \pm 0.64$ & $0.41 \pm 0.31$ & $0.24 \pm 0.14$ & $0.22 \pm 0.09$ & 0.03 & \\
\hline $\mathrm{Cu}$ & $0.10 \pm 0.08$ & $0.09 \pm 0.05$ & $0.08 \pm 0.02$ & $0.09 \pm 0.05$ & 0.70 & \\
\hline $\mathrm{Pb}$ & $1.90 \pm 0.74$ & $1.11 \pm 0.60$ & $1.05 \pm 0.35$ & $1.01 \pm 0.51$ & 1.0 & \\
\hline $\mathrm{Zn}$ & $69.5 \pm 7.04$ & $32.8 \pm 4.23$ & $17.4 \pm 3.17$ & $11.2 \pm 2.09$ & 0.50 & \\
\hline
\end{tabular}

of $\mathrm{Cu}, \mathrm{Zn}, \mathrm{Pb}$ and $\mathrm{Cd}$ were observed in the needles of sensitive trees compared with resistant trees. This difference in metal accumulation between sensitive and resistant pines follows the order (expressed in \%):

$$
\text { P.sylvestris: } \quad \mathrm{Pb}(27.5)>\mathrm{Cu}(25.0)>\mathrm{Cd}(21.1)>\mathrm{Zn}(10.5)
$$$$
\text { P.nigra: } \quad \mathrm{Cu}(40.0)>\mathrm{Cd}(13.7)>\mathrm{Zn}(7.5)>\mathrm{Pb}(6.2)
$$

These findings are important in terms of survival of both species in such a heavily contaminated area. The narrowest difference between the two species was that reported for $\mathrm{Zn}$ : $10.5 \%$ in P. sylvestris compared with $7.5 \%$ in P. nigra.

\section{Allele frequencies}

A total of 12 loci for P. sylvestris and 14 for P. nigra were analysed (Tables 2 and 5). All loci were polymorphic, except for the MDH A locus, which was monomorphic in the $P$. nigra population. A larger number of alleles (38 for $P$. sylvestris and 34 for $P$. nigra) and a higher mean number of alleles per locus (3.2 and 2.4, respectively) were found in the group of sensitive trees than in the group of pollution-resistant trees (35 for $P$. sylvestris and 31 for $P$. nigra; Table 6).

Three private alleles, associated with 6PGD, GOT B and DIAF loci, were recorded in sensitive trees of $P$. sylvestris. For $P$. nigra, there were four private alleles at FEST, SHDH A and GOT $\mathrm{A}$ and $\mathrm{C}$ loci in the $\mathrm{S}$ group, and at the FEST locus in the resistant group (Table 5).

The differences in allele frequency between sensitive and resistant tree groups were $20-64 \%$ in $P$. sylvestris and 25 $77 \%$ in $P$. nigra. At five of the analysed loci (FEST, SHDH A and B, GOT B and PGI), such differences were identified in both species. Principal component analysis (PCA) performed based on allele frequencies distinguished the two pine species and confirmed the uniqueness of sensitive and resistant subpopulations of $P$. nigra (Fig. 1; $93 \%$ of explained variation). The Ewens-Watterson test for neutrality (Table 7) revealed that the pattern of allele frequencies at the locus GOT B of black pine subpopulations was not selectively neutral $(P<0.05)$, but was influenced by selection processes. Results obtained by applying the method of Vitalis et al. (2001) using DetSel software also suggest that GOT B as well as loci NDH, SHDH B, MDH C and GDH are probably under selection pressure (Fig. 2).

A higher observed heterozygosity $\left(H_{\mathrm{o}}\right)$ was identified in the sensitive tree group at six out of 12 analysed loci in $P$. sylvestris (Fig. 3a), and at seven out of 14 loci in P. nigra (Fig. 3b). The differences were as high as $26 \%$ in $P$. sylvestris and $35 \%$ in $P$. nigra. By the same token, a higher $H_{\mathrm{o}}$ level was found in resistant trees at five loci (ca. $18 \%$ ) of $P$. sylvestris and at six loci (ca. $23 \%$ ) of P. nigra. In contrast, four loci (6PGD, GDH, PGI and SHDH B) displayed a reverse trend in heterozygosity in sensitive and resistant trees in both
Table 4 Mean heavy metal contents in 1-year-old needles of $P$. sylvestris and $P$. nigra $(n=50$ in each subpopulation)

\footnotetext{
${ }^{\text {a }}$ Mean value with standard deviation

${ }^{\mathrm{b}}$ Markert (1994)

${ }^{\mathrm{c}}$ Pais and Benton Jones (1997)
}

\begin{tabular}{llllll}
\hline Species & Subpopulation & $\begin{array}{l}\mathrm{Cu} \\
\mathrm{mg} \mathrm{kg}\end{array}$ & $\mathrm{Zn}$ & $\mathrm{Pb}$ & $\mathrm{Cd}$ \\
\hline P. sylvestris & Resistant (R) & $4.0 \pm 1.3^{\mathrm{a}}$ & $193.6 \pm 59.3$ & $196.7 \pm 76.8$ & $1.75 \pm 0.46$ \\
& Sensitive (S) & $5.0 \pm 1.1$ & $213.9 \pm 50.6$ & $250.7 \pm 71.6$ & $2.12 \pm 0.74$ \\
P. nigra & Resistant (R) & $3.0 \pm 1.0$ & $162.5 \pm 42.8$ & $158.5 \pm 56.7$ & $1.24 \pm 0.66$ \\
& Sensitive (S) & $4.2 \pm 1.4$ & $174.7 \pm 43.7$ & $168.3 \pm 52.9$ & $1.41 \pm 0.65$ \\
'Reference plant'b, c & 10 & 50 & 1.0 & 0.05 \\
\hline
\end{tabular}


Table 5 Frequencies of alleles in the sensitive (S) and resistant $(\mathrm{R})$ trees of $P$. sylvestris (P. s.) and P. nigra (P. n.)

\begin{tabular}{|c|c|c|c|c|c|c|c|c|c|}
\hline \multirow{2}{*}{\multicolumn{5}{|c|}{ of P. sylvestris (P. s.) and P. nigra (P. n.) }} & \multirow{2}{*}{ Locus/allele } & \multirow{2}{*}{ P. s. (S) } & \multirow{2}{*}{ P. s. (R) } & \multirow{2}{*}{ P. n. (S) } & \multirow{2}{*}{ P. n. (R) } \\
\hline & & & & & & & & & \\
\hline Locus/allele & P. s. (S) & P. s. (R) & P. n. (S) & P. n. (R) & & & & & \\
\hline \multirow{2}{*}{\multicolumn{5}{|c|}{ FEST }} & 2 & 0.038 & 0.029 & 0.176 & 0.220 \\
\hline & & & & & 3 & 0.108 & 0.133 & 0.059 & 0.120 \\
\hline 1 & 0.746 & 0.788 & 0.697 & 0.865 & 4 & 0.008 & 0.008 & 0.000 & 0.000 \\
\hline 2 & 0.142 & 0.121 & 0.273 & 0.122 & PGM & & & & \\
\hline 3 & 0.104 & 0.088 & 0.030 & 0.000 & 1 & 0.000 & 0.000 & 0.845 & 0.797 \\
\hline 5 & 0.008 & 0.004 & 0.000 & 0.014 & 2 & 0.000 & 0.000 & 0.138 & 0.149 \\
\hline \multicolumn{5}{|l|}{ 6PGD } & 3 & 0.000 & 0.000 & 0.017 & 0.054 \\
\hline 1 & 0.788 & 0.829 & 0.727 & 0.764 & $\mathrm{NDH}$ & & & & \\
\hline 2 & 0.204 & 0.167 & 0.273 & 0.236 & 1 & 0.000 & 0.000 & 0.833 & 0.897 \\
\hline 3 & 0.004 & 0.004 & 0.000 & 0.000 & 2 & 0.000 & 0.000 & 0.167 & 0.103 \\
\hline
\end{tabular}

ShDH A

$\begin{array}{lllll}1 & 0.867 & 0.867 & 0.734 & 0.824 \\ 2 & 0.067 & 0.079 & 0.234 & 0.176 \\ 3 & 0.054 & 0.038 & 0.000 & 0.000 \\ 5 & 0.013 & 0.017 & 0.031 & 0.000\end{array}$

ShDH B

$\begin{array}{ccccc}1 & 0.933 & 0.933 & 0.939 & 0.986 \\ 2 & 0.063 & 0.058 & 0.061 & 0.014 \\ 3 & 0.004 & 0.008 & 0.000 & 0.000 \\ \text { MDH A } & & & & \\ 1 & 0.929 & 0.975 & 1.000 & 1.000 \\ 2 & 0.071 & 0.025 & 0.000 & 0.000\end{array}$

\section{MDH C}

2

GDH

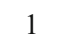

2

DIAF

\section{1}

2

4

GOT A

1
2
3

GOT B

$\begin{array}{ll}1 & 0.625 \\ 2 & 0.367 \\ 3 & 0.004 \\ 4 & 0.004\end{array}$

GOT C

1
2
3
4
PGI
1

0.729

0.271

0.317

0.683

0.854

0.138

0.008

0.892

0.000

0.108

0.725

0.275

0.545

0.455

0.367

0.633

0.879

0.121

0.000

0.900

0.000

0.100

0.583

0.408

0.008

0.000

0.683

0.296

0.017

0.004

0.829
0.094

0.906

0.950

0.017

0.033

0.818

0.045

0.136

0.364

0.636

0.000

0.000

0.759

0.224

0.017

0.000

0.765
Table 5 (continued)

species. FEST, SHDH A and DIA loci exhibited a higher heterozygosity in sensitive trees, as did GOT B and C loci in resistant trees (Fig. 3a and b). Differentiation with respect to heterozygosity levels in pine species and sensitive/resistant subpopulations was also confirmed by PCA (Fig. 4).

Wright's $F$ index revealed that there was statistically significant excess of homozygosity in tolerant trees of $P$. sylvestris at loci SHDH A, GDH and MDH A and of $P$. nigra at loci SHDH A, DIA and PGM (Table 8). At the other loci, the group exhibited a status close to Hardy-Weinberg equilibrium. In the sensitive group of $P$. sylvestris, a statistically significant reduced heterozygosity was found at loci GOT C, PGI and SHDH A (Fig. 5a; Table 8), however, with a similar trend identified in sensitive P. nigra at SHDH B (Fig. 5b; Table 8). The mean Wright's $F$ index calculated for all loci was similar for sensitive and resistant groups in $P$. sylvestris (0.079 and 0.076 , respectively). In contrast, it varied considerably in P. nigra (0.094 vs. 0.044; Fig. 5b). The MannWhitney $U$ test revealed statistically significant $(P<0.05)$ differences among sensitive and resistant subpopulations of black pine with regard to Wright's $F$ index calculated for six loci with higher $H_{\mathrm{o}}$ in resistant trees.

An analysis of molecular variance on all loci indicated that Scots pine had the largest variance within individuals (92\%), but a variance of only $8 \%$ among individuals. The highest variance among individuals in this species (17-19\%) was found at four loci: SHDH A, GDH, GOTC and PGI (Table 9). In sensitive and resistant subpopulations of black pine, the

Table 6 Allele statistics in the sensitive (S) and resistant (R) trees of $P$. sylvestris (P. s.) and P. nigra (P. n.)

\begin{tabular}{lllll}
\hline Parameter & P. s. (S) & P. s. (R) & P. n. (S) & P. n. (R) \\
\hline No. of trees & 50 & 50 & 50 & 50 \\
No. of alleles & 38 & 35 & 34 & 31 \\
No. of alleles per locus & 3.2 & 2.9 & 2.4 & 2.2 \\
No. of private alleles & 6 & 0 & 4 & 1 \\
\hline
\end{tabular}


Fig. 1 Principal component analysis calculated on the allele frequencies in subpopulation $\mathrm{S}$ and $\mathrm{R}$ of $P$. sylvestris and $P$. nigra

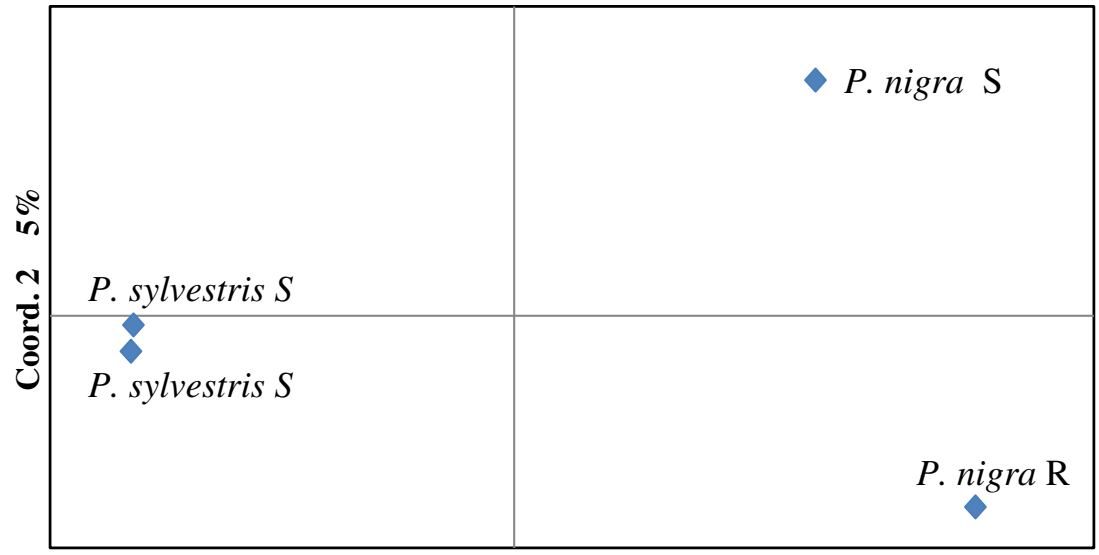

Coord. $194 \%$ proportion of genetic variation relative to total population variation $\left(F_{\mathrm{ST}}\right)$ was $1 \%$, with variance of $37 \%$ among individuals and $62 \%$ within individuals. High variation was observed between individual loci (Table 9). Genetic distances among sensitive and resistant subpopulations were 0.001 in $P$. sylvestris and 0.009 in P. nigra.

\section{Discussion}

P. sylvestris and P. nigra in the contaminated environment - a reference trial

As first suggested by Markert (1994) and later by Pais and Benton Jones (1997), metal concentrations can be compared

Table 7 The Ewens-Watterson (Manly 1985) test for neutrality for subpopulations sensitive (S) and resistant (R) of P. nigra: k: no. of alleles; obs. F: observed sum of the squared of allelic frequency calculated using 1,000 simulated samples; L95, U95: the $95 \%$ confidence interval lower and upper limit

\begin{tabular}{lllll}
\hline Locus & K & obs. F & L95 & U95 \\
\hline FEST & 3 & 0.7630 & 0.3649 & 0.9470 \\
6PGD & 2 & 0.6393 & 0.5015 & 0.9726 \\
SHDH A & 2 & 0.7104 & 0.5015 & 0.9733 \\
SHDH B & 2 & 0.9733 & 0.5015 & 0.9733 \\
MDHA & 1 & 1.0000 & - & - \\
MDH C & 2 & 0.5296 & 0.5015 & 0.9733 \\
GDH & 2 & 0.8104 & 0.5005 & 0.9702 \\
DIAF & 3 & 0.9194 & 0.3638 & 0.9456 \\
GOT A & 2 & 0.6107 & 0.5017 & 0.9429 \\
GOT B & 2 & 0.5000 & 0.5015 & 0.9726 \\
GOT C & 2 & 0.5638 & 0.5026 & 0.9649 \\
PGI & 3 & 0.4984 & 0.3592 & 0.9224 \\
PGM & 3 & 0.6607 & 0.3649 & 0.9470 \\
NDH & 2 & 0.8145 & 0.5024 & 0.9661 \\
\hline
\end{tabular}

among plants growing in different ecosystems using a "reference plant" (Table 4). In this technique, analytical data are standardised against a reference plant, with fingerprint graphs subsequently generated that display positive or negative percentage deviations from reference plant values. According to Markert (1996), reference plant standardisation allows both extremely high element concentrations as well as minimal values of individual elements in a sample to be taken into consideration to the same degree. Data listed in Table 10 outline the percentage deviation of $\mathrm{Cu}, \mathrm{Zn}, \mathrm{Pb}$ and $\mathrm{Cd}$ concentrations of both pine species as compared to the reference plant.

One advantage of such a representation is the ability to portray element distribution patterns within a plant species without having to display a widespread of element concentration ranges, which occur in varying orders of magnitude, and without having to resort to logarithmic scales (Breulmann et al. 1999). Because $\mathrm{Cu}$ concentrations were below those of the reference plant, deviations were negative for both $P$. sylvestris and $P$. nigra (Table 10). Very high positive deviations occurred in the case of $\mathrm{Cd}$, with strikingly high deviations for $\mathrm{Pb}$. These two metals may be growth-limiting factors responsible for the genetic disturbance observed in investigated needles. Based on the high metal concentrations detected in soils, we assume that the transfer of $\mathrm{Pb}, \mathrm{Cd}$ and $\mathrm{Zn}$ from soils to growing pines was facilitated by geochemical conditions, i.e. predominance of the sand fraction and very acid soil. Significantly high deviations have been reported by Breulmann et al. (1999) for $\mathrm{Co}$ and $\mathrm{Ni}-6,700$ and $559 \%$, respectively, in the case of Euphorbiaceae from a mixed dipterocarp forest in Sarawak, Malaysia. In that study, positive deviations for Ni observed both in Dipterocarpaceae and Euphorbiaceae were attributed to a possibly higher uptake at lower $\mathrm{pH}$ values. Our deviation data, based on the concept of Markert's reference plant, are the first established for Polish conditions and particularly for $P$. sylvestris and $P$. nigra. Because of its high tolerance to soil contamination by trace 


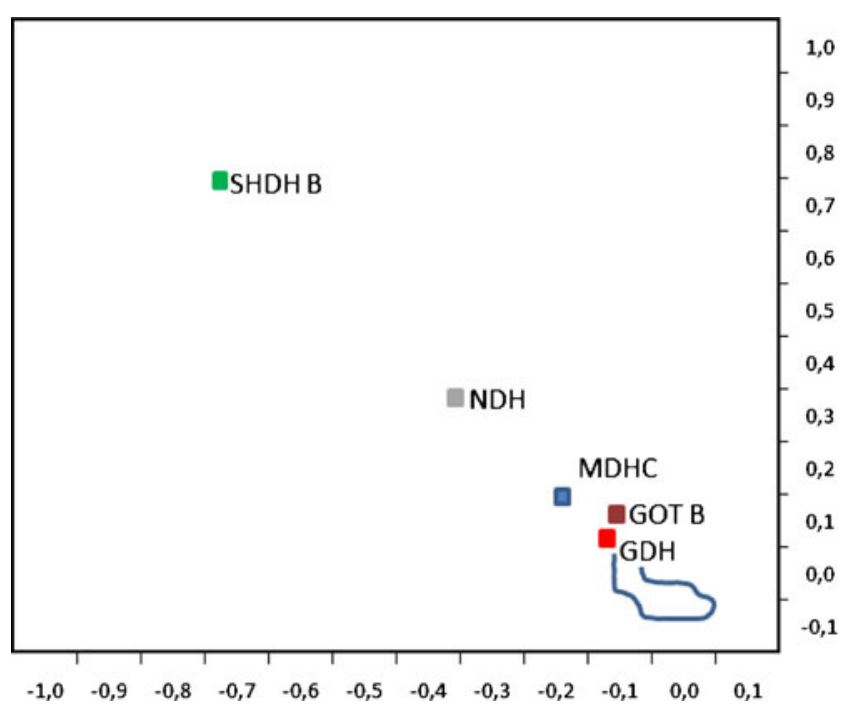

Fig. 2 The results from the program DetSel. Expected distribution of parameters $F_{1}$ and $F_{2}$ estimates conditioned on a number of alleles in the subpopulation $\mathrm{S}$ and $\mathrm{R}$ of $P$. nigra. The loci found to lie outside or on the limit of the $95 \%$ high probability region allowed by a neutrality model are expected to be under selection

metals, black pine has been used for many years for reforestation of lands near metallurgical plants (Pavlik et al.
2012). It should also be mentioned that because it grows well on poorer soils, black pine sometimes replaces native species, such as Scots pine, that are often unable to grow in contaminated areas.

Genetic differentiation - pine's survival strategy?

Genetic variation is one of the aspects analysed during studies of plant recolonisation of former industrial areas. A gradual improvement in environmental conditions promotes natural regeneration of forests, including on soils degraded by metalcontaining dust emissions. According to our observations, this is a slow process because of the accumulation of heavy metals in soil and their continued assimilation by plants. The clear differentiation, in terms of fitness and genetic diversity, between sensitive and resistant Scots and black pine trees in the regenerated population is very interesting. Some parameters, such as mean observed heterozygosity at all loci, did not differ between the two groups. When individual loci were examined, however, the parameter varied substantially, not only between species but also between sensitive and resistant subpopulations. Regardless of species, $H_{\mathrm{o}}$ values in roughly half of all loci are higher in sensitive trees, i.e. those with a high
Fig. 3 a, b Observed heterozygosity $H_{\mathrm{o}}$ in sensitive $(S)$ and resistant $(R)$ trees of $P$. sylvestris population. $X$-axis, isoenzymatic loci; $Y$-axis, value of the observed heterozygosity

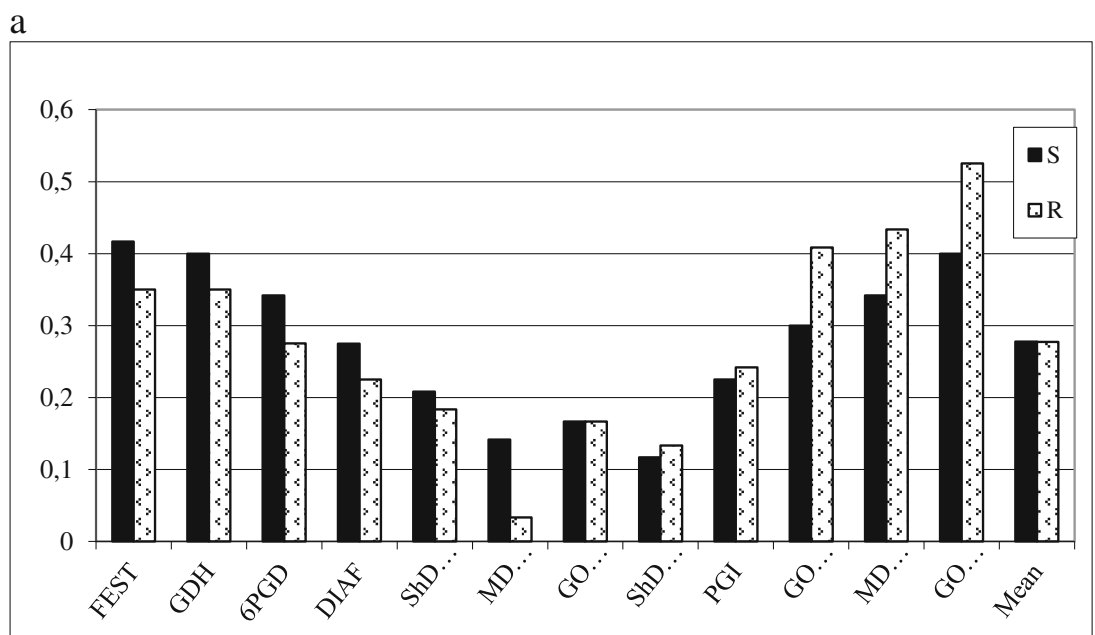

b

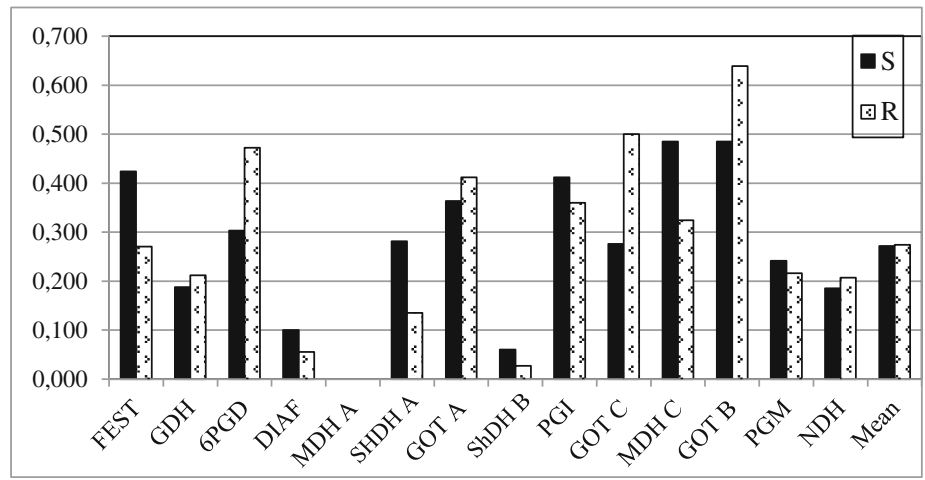


Fig. 4 Observed heterozygosity $H_{\mathrm{o}}$ in sensitive $(S)$ and resistant $(R)$ trees of $P$. nigra population. $X$-axis, isoenzymatic loci; $Y$-axis, value of the observed heterozygosity

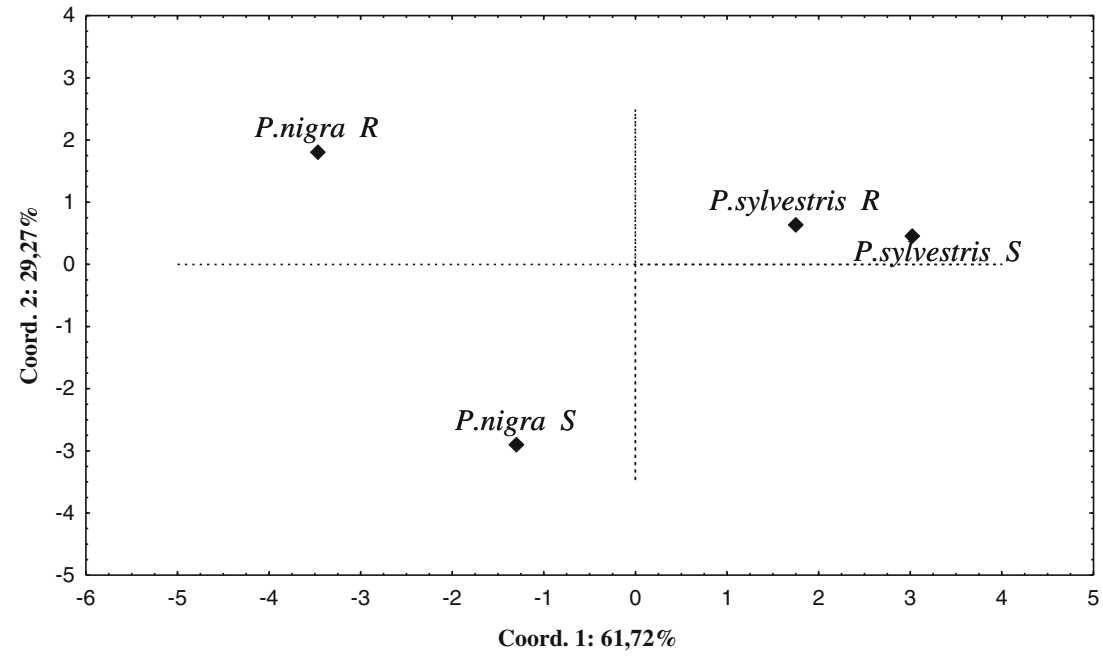

degree of crown damage, thinning or absence of 2-year-old needles and low seed quality. Statistically significant reduced heterozygosity was exhibited at the SHDH-A locus in resistant groups of both pine species; this has also been observed, for example, in common beech growing on polluted land (Longauer et al. 2001). At two other loci (GOT B and C), in contrast, $H_{\mathrm{o}}$ was higher in the resistant group. Allele frequency differences between sensitive and resistant groups occurred both in Scots and black pine species. The Ewens-Watterson test for neutrality confirmed that allele frequencies at locus GOT B of $P$. nigra have been influenced by selection, acting either directly on this locus or on adjacent genomic regions. Based on the test of Vitalis et al. (2001), GOT B, which showed excess heterozygosity in resistant subpopulations, as

Table 8 Summary of chi-square tests for Hardy-Weinberg equilibrium in the sensitive (S) and resistant (R) trees of P. sylvestris (P. s.) and $P$. nigra (P. n.)

\begin{tabular}{llllll}
\hline Population & DF & Chi square & Probability & Significance & $F$ value \\
\hline P. sylvestris & & & & & \\
S & 6 & 13.057 & 0.042 & $*$ & 0.137 \\
S & 6 & 14.223 & 0.027 & $*$ & 0.260 \\
S & 6 & 12.599 & 0.050 & $*$ & 0.171 \\
R & 6 & 54.030 & 0.000 & $* * *$ & 0.239 \\
R & 1 & 12.001 & 0.001 & $* * *$ & 0.316 \\
R & 1 & 7.286 & 0.007 & $* *$ & 0.246 \\
P. nigra & & & & & \\
S & 1 & 7.220 & 0.007 & $* *$ & 0.468 \\
R & 1 & 10.528 & 0.001 & $* *$ & 0.533 \\
R & 3 & 35.486 & 0.000 & $* * *$ & 0.311 \\
R & 3 & 11.984 & 0.007 & $* *$ & 0.363 \\
\hline
\end{tabular}

$S$ sensitive trees, $R$ resistant trees, $D F$ degree of freedom, $F$ Wright's index

${ }^{*} P<0.05 ; * * P<0.01 ; * * * P<0.001$ well as GDH, MDH C, NDH and SHDH B, appeared to be under selection pressure. Significant excess of homozygosity was found at loci SHDH B and NDH in sensitive trees and at locus $\mathrm{MDH} \mathrm{C}$ in resistant trees. Elevated $H_{\mathrm{o}}$ levels among trees sensitive to heavy metal stress were recorded for FEST and DIA.

With respect to the remaining loci, trends varied depending on species. At locus 6PGD in the Scots pine resistant group, we found a higher frequency of homozygotes $1 / 1$ and $2 / 2$, a lower frequency of heterozygote $1 / 2$ and lower observed heterozygosity levels. An opposite trend was identified in P. nigra.

A significant role for the 6PGD enzyme was also emphasised by Hosius and Bergmann (1994) in the adaptation of Norway spruce to heavy-metal-contaminated soils. The authors pointed to a stabilizing selection effect, because the frequency of heterozygote 6PGD 1/2 increased under stress conditions and thus showed the highest viability; this was also noted in the $P$. nigra population from Miasteczko Slaskie. A potential heterozygote advantage for 6PGD-1 in pine was also revealed in a study by Savolainen and Hedrick (1995). In our study, the GDH homozygote 1/1 frequency in Scots pine was found to be $39 \%$ higher in the resistant tree group. The same trend was reported by Geburek et al. (1987) in investigations of $P$. sylvestris trees sensitive or resistant to air pollutants, and by Prus-Głowacki and Nowak-Bzowy (1992). In black pine, heterozygote GDH $1 / 2$ frequency was higher in resistant trees. Another locus of interest is $\mathrm{MDH}$, for which Longauer et al. (2001), in studies of Norway spruce (MDH C) and silver fir (MDH A), reported a "significant deviation towards heterozygote deficiency in the declining tree set", while in our results heterozygote deficiency was observed at $\mathrm{MDH}$ A locus in resistant Scots pine trees and at MDH C in black pine.

Based on Wright's $F$ index, no significant excess of heterozygotes was found in any subpopulations from either pine species. The distribution of $F$ values in individual loci and 
Fig. 5 a, b Principal component analysis calculated on the observed heterozygosity values in the analysed loci in subpopulation $\mathrm{S}$ and $\mathrm{R}$ of $P$. sylvestris and $P$. nigra

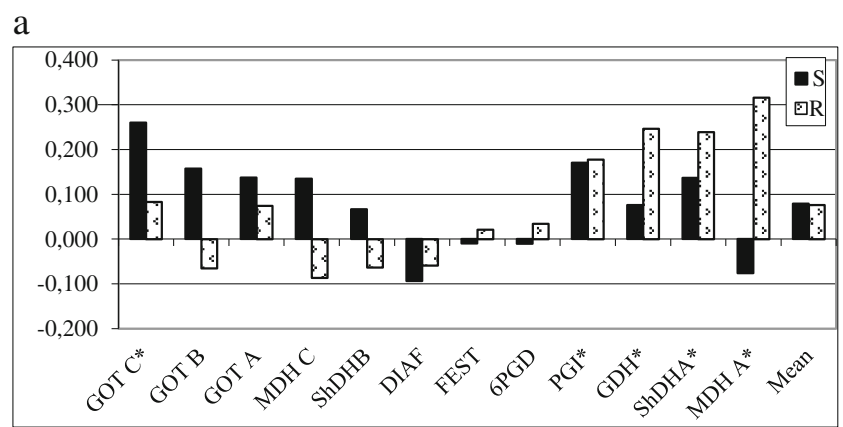

b

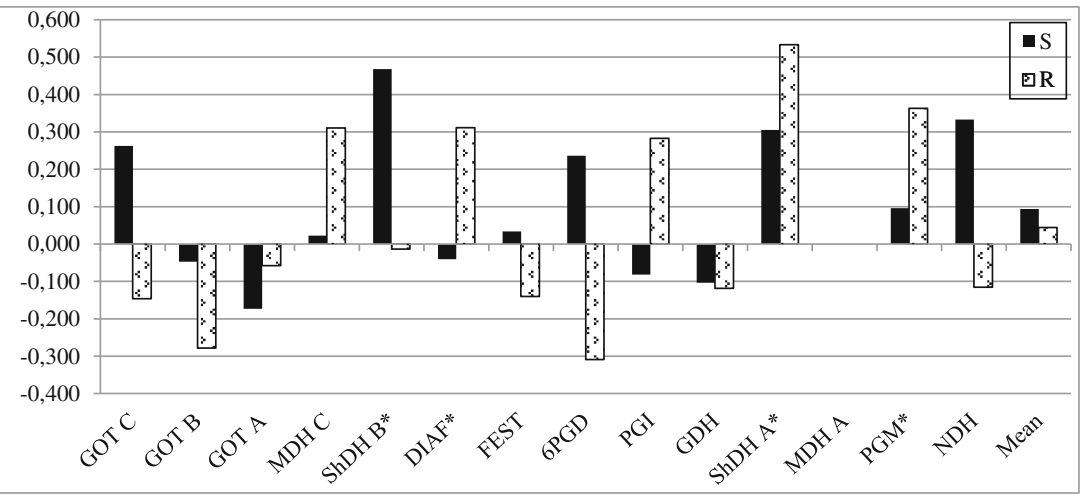

Table 9 Results of analysis of molecular variance PhiPT (AMOVA) for sensitive (S) and resistant (R) subpopulations of $P$. sylvestris and $P$. nigra

\begin{tabular}{|c|c|c|c|c|c|c|}
\hline \multirow[t]{2}{*}{ Locus } & \multicolumn{3}{|c|}{ P. sylvestris } & \multicolumn{3}{|l|}{ P. nigra } \\
\hline & $\begin{array}{l}\text { Among } \\
\text { subpops. }^{\text {a }} \\
\%\end{array}$ & $\begin{array}{l}\text { Among } \\
\text { indiv. }^{\mathrm{b}}\end{array}$ & $\begin{array}{l}\text { Within } \\
\text { indiv. }^{b}\end{array}$ & $\begin{array}{l}\text { Among } \\
\text { subpops. }^{\text {a }}\end{array}$ & $\begin{array}{l}\text { Among } \\
\text { indiv. }^{\mathrm{b}}\end{array}$ & $\begin{array}{l}\text { Within } \\
\text { indiv. }^{\text {b. }}\end{array}$ \\
\hline FEST & 0 & 1 & 99 & 6 & 0 & 94 \\
\hline 6PGD & 0 & 1 & 99 & 0 & 4 & 96 \\
\hline ShDH A & 0 & 19 & 81 & 0 & 46 & 54 \\
\hline ShDH B & 0 & 1 & 99 & 1 & 38 & 61 \\
\hline $\mathrm{MDH} A$ & 2 & 3 & 95 & 0 & 0 & 0 \\
\hline $\mathrm{MDH} \mathrm{C}$ & 0 & 3 & 97 & 0 & 18 & 82 \\
\hline GDH & 0 & 17 & 83 & 0 & 36 & 64 \\
\hline DIAF & 0 & 0 & 100 & 0 & 62 & 38 \\
\hline GOT A & 0 & 11 & 89 & 5 & 61 & 34 \\
\hline GOT B & 0 & 5 & 95 & 2 & 0 & 98 \\
\hline GOT C & 0 & 17 & 83 & 1 & 45 & 54 \\
\hline PGI & 0 & 18 & 82 & 1 & 62 & 37 \\
\hline PGM & 0 & 0 & 0 & 1 & 44 & 55 \\
\hline $\mathrm{NDH}$ & 0 & 0 & 0 & 0 & 67 & 33 \\
\hline Mean & 0 & 8 & 92 & 1 & 37 & 62 \\
\hline
\end{tabular}

${ }^{\text {a }}$ Subpopulations

${ }^{\mathrm{b}}$ Individuals subpopulations was generally quite similar in both pine species. At some analysed loci, reduced heterozygosity was observed in sensitive trees; at other loci, however, an opposite tendency was noted, with higher levels found in resistant trees. The mean $F$ value (calculated for loci with a higher $H_{\mathrm{o}}$ in resistant trees) was statistically significant (Mann-Whitney $U$ test, $P<0.05$ ) among sensitive and resistant subpopulations of black pine. In previous studies on Scots pine, resistant subpopulations exhibited higher frequencies of heterozygotes at most enzyme gene loci (Ziehe et al. 1999; Prus-Głowacki et al. 2006).

"Fittest" genotypes

Although stress from heavy-metal-contaminated soil affected individual Black and Scots pine trees similarly, certain

Table 10 Percentage deviation of analysed metals with respect to the 'Reference plant' in 1-year-old needles $P$. sylvestris and $P$. nigra

\begin{tabular}{llllll} 
Species & Subpopulation & $\begin{array}{l}\mathrm{Cu} \\
\% \text { deviation }\end{array}$ & $\mathrm{Zn}$ & $\mathrm{Cd}$ \\
\hline P. sylvestris & Resistant (R) & -60 & 287 & 19,570 & 3,400 \\
& Sensitive (S) & -50 & 328 & 24,970 & 4,140 \\
P. nigra & Resistant (R) & -70 & 225 & 15,750 & 2,380 \\
& Sensitive (S) & -58 & 250 & 16,730 & 2,720 \\
\hline
\end{tabular}


differences were observed among particular isoenzyme loci upon analysis. Some loci exhibited lower levels of genetic variation in resistant subpopulations of both pine species. The reduced variation observed in the well-adapted group might be a manifestation of the "survival of the fittest" rule, with better-fit individuals being homozygous (Bergman and Hosius 1996; Prus-Glowacki and Godzik 1991). There is, however, another point of view. In the studied pine populations, a stabilizing selection effect was evident in half of the analysed loci, as heterozygote frequency increased in pollution-resistant trees of $P$. sylvestris (GOT A, B, C, MDH $\mathrm{C}, \mathrm{SHDH} \mathrm{B}$ and PGI) and P. nigra (GOT A, B, C, GDH, $\mathrm{NDH}$ and 6PGD). In general, less-damaged trees demonstrated a greater degree of genetic variation, meaning that more heterozygous individuals were better adapted to environmentally stressful conditions. This observation is consistent with the hypothesis of heterozygote superiority still presented in contemporary research (Patrice 1998; Hanson and Westerberg 2002; Prus-Głowacki et al. 2006; Staszak et al. 2007). If an adaptation strategy is linked to the loss of genetic richness through elimination of some alleles (in homozygotes), the genetic cost of adaptation involves impoverishment of a population's gene pool. The observed genetic diversity in studied populations of Scots and black pines is probably the result of two genetic processes: selection pressure of the contaminated environment and mutations at the molecular and cytogenetic level induced by heavy metals. Because investigated trees were naturally regenerated from seeds of few mother trees, a higher level of homozygosity was expected as a consequence of inbreeding. The excess homozygosity should have been reduced, however, in the 35-40-year-old trees studied. As pointed out by Althukov (2003), heterozygote deficiency in embryos is eliminated in subsequent ontogenic stages and reaches a genetic optimum specific to each species. We thus conclude that strong selection pressure of the heavily damaged environment was the primary influence on genetic diversity of the studied populations.

Based on results reported above and from other studies, it can be argued that the advantage (or disadvantage) of a genotype is mainly dependent on a particular gene locus. The isozyme data elaborated in this study suggest that some isozyme genotypes may have a viability advantage/ disadvantage correlation. This cannot be linked to singlegene effects, because tolerance and resistance in trees, as in most plants, is predominantly controlled by polygenes. If allozyme loci tend to be in gene-rich regions, however, these loci would be more likely to be in linkage disequilibrium with other loci affecting fitness (Hanson and Westerberg 2002).

Such an adaptation strategy in a naturally regenerated population leads to a narrowing of the gene pool. This model assumes a strong directional selection pressure of the environment, which favours strictly specialised genotypes well- adapted to a given set of conditions. This situation has been observed in Norway spruce, European silver fir, common beech and Black and Scots pine (Longauer et al. 2001; Serbula et al. 2012; Korshikov et al. 2005).

\section{Differences and similarities between pine species}

Similar tendencies observed in trees with better fitness are interesting, but fail to account for the inter-species differences in resistance uncovered in our study. We note the very high proportion of inter-individual variation observed in the black pine population $\left(F_{\mathrm{ST}}\right.$ up to $67 \%$ in individual loci and $37 \%$ in total) and the $1 \%$ variation between sensitive and resistant subpopulations (1-6\% in individual loci). These findings are consistent with results obtained by Scaltsoyiannes et al. (2008), who uncovered more distinct differentiation among populations of $P$. nigra (at least 2 -fold higher $G_{\mathrm{ST}}$ values) than among $P$. sylvestris. This may be a consequence of different evolutionary pathways, particularly during postglacial periods, of the two pine species. According to a theory formulated by Gullberg et al. (1985), natural species that were strongly affected by glaciation, such as Scots pine, currently exhibit little differentiation among populations. Species such as black pine, which were not significantly affected by glaciation, are conversely characterised by greater inter-population differentiation and a higher number of rare alleles. Based on the results of our study, $P$. nigra is clearly more strongly differentiated than $P$. sylvestris in regard to genetic parameters such as allele frequency, $H_{\mathrm{o}}$, Wright's index and $F_{\mathrm{ST}}$ and, therefore, exhibits markedly higher variation in the genetic structure of its sensitive and resistant subpopulations.

\section{Conclusions}

In our study, higher $\mathrm{Zn}, \mathrm{Pb}, \mathrm{Cd}$ and $\mathrm{Cu}$ contents were observed in needles of sensitive $P$. sylvestris compared with resistant $P$. nigra trees. The health condition of Scots pines was worse than that of black pines; although trees of the latter species were characterised by a lower metal content, concentrations in 1 -year-old needles, except for that of $\mathrm{Cu}$, significantly exceeded reference plant values.

Sensitive and resistant trees, which differed in fitness, exhibited differences in their genetic structures. The greatest differentiation between the two subpopulations was observed in the loci of enzymes involved in metabolic pathways, whose activity is modified by heavy metal ions. The adaptation strategy of resistant Scots and black pine trees is the result of two processes acting in different loci: (1) strong directional selection favouring strictly specialised homozygous genotypes (reduction in the level of genetic variation) and (2) stabilizing selection increasing heterozygote frequency 
(elimination of homozygotes). We conclude that the genetic cost of adaptation involves impoverishment of population gene pools owing to the complex and long-lasting impact of heavy metals, primarily $\mathrm{Pb}, \mathrm{Zn}$ and $\mathrm{Cd}$.

The potential for culturing pines resistant to industrial pollution may be important since the role of forest ecosystems in revitalizing areas degraded by industry does not weaken. The maintenance of forest ecosystem stability should increase the diversity within the population of trees (Schaberg et al. 2008). This statement has been supported by our data, which explicitly detailed the process of genetic enrichment and/or impoverishment induced by metal pollution. From the practical point of view, the re-cultivation via pines may be successfully operated by amplifying heavy-metal-resistant genotypes.

This process must be strictly site-specific and possibly oriented to the most persistent and harmful contaminant. In our opinion further studies as well as management practices should be focused both on the exploration of native plant material for collecting gene pools less susceptible to pollution impact and on the enrichment of the genetic diversity.

Acknowledgments This study was financially supported by Polish NCN grant no. 0584/B/P01/2011/40, Comparison of micro-evolutional processes taking place in two bioindicator species; Pinus nigra Arn. and Pinus sylvestris L. growing in a heavy polluted environment.

Open Access This article is distributed under the terms of the Creative Commons Attribution License which permits any use, distribution, and reproduction in any medium, provided the original author(s) and the source are credited.

\section{References}

Acquaviva R, Vanella L, Sorrenti V, Santangelo R, Iauk L, Russo A, Savoca F, Barbagallo I, Di Giacomo C (2012) Biochemical modifications in Pinus pinaster Ait. as a result of environmental pollution. Environ Sci Pollut Res. doi:10.1007/s11356-012-1030-x

Altukhov Yu P (2003) Genetic processes in populations. Manual. $3^{\text {ed }}$. Rev. and enl. PTC "Academkniga" Moscow: 431

Au DWT (2012) New directions in ecotoxicology and meeting the challenges ahead. 15th international symposium on toxicity assessment. Environ Sci Pollut Res 19:2463-2464

Benavides MP, Gallego SM, Tomaro ML (2005) Cadmium toxicity in plants. Braz J Plant Physiol 17(1):21-34

Bergmann F, Hosius B (1996) Effect of heavy-metal polluted soils on the genetic structure of Norway spruce seedling populations. Water Air Soil Poll 89:363-373

Breulmann G, Ogino K, Markert B, Leffler US, Herpin U, Weckert V, Konschak R, Kikugawa Y, Ohkubo T (1999) Comparison of chemical elements in Dipterocarpaceae and Euphorbiaceae from a tropical rain forest in Sarawak. Malaysia Sci Total Environ 225: 231-240

Cheliak WM, Pitel JA (1984) Techniques for starch gel electrophoresis of enzymes from forest tree species. Report PI-X-42, 1-49. Agriculture Canada, Canadian Forestry Service, Chalk River, Ontario, Canada

Chudzińska E, Urbaniak L (2008) Pinus sylvestris L. response to heavy metal contamination express in anatomical traits of needles. W
"Zarządzanie ochroną przyrody w lasach" praca zbiorowa pod red. K. Kannenberga i H. Szramki, t. II, 72-84

Conkle MT, Hodgskiss PD, Nunnally LB, Hunte SC (1982) Starch gel electrophoresis of conifer seeds: a laboratory manual. USDA Serv Tech Rep PSW-64

Diatta JB, Chudzinska E, Wirth S (2008) Assessment of heavy metal contamination of soils impacted by a zinc smelter activity. J Elementol 13(1):5-16

Diatta J, Wirth S, Chudzinska E (2011) Spatial distribution of Zn, Pb, Zn, $\mathrm{Cd}$ and dynamics of bioavailable forms at Polish metallurgical site. Fresen Environ Bull 20(4):976-982

Directive of Polish Minister of Environmental Protection and Forest Resources for Soil and Earth Quality (2002) Dziennik Ustaw 165, poz. 1359 (in Polish)

Dubois S, Cheptou PO, Petit C, Meerts P, Poncelet M, Vekemans X, Lefèvre C, Escarré J (2003) Genetic structure and mating systems of metallicolous and nonmetallicolous populations of Thlaspi caerulescens. New Phytol 157:633-641

Galibina NA, Terebova EN (2008) Characterization of cell wall properties in needles from Scotch Pine trees of various vigor. Russ J Plant Physl 55(3):378-384

Geburek T, Scholz F, Knabe W, Vornweg A (1987) Genetic studies by isozyme gene loci on tolerance and sensitivity in an air polluted Pinus sylvestris field trial. Silvae Genet 36:49-53

Gullberg U, Yazdani R, Rudin D, Ryman N (1985) Allozyme variation in Scott pine (Pinus sylvestris L.) in Sweden. Silvae Genet 34(6):193201

Gupta SK, Aten C (1993) Comparison and evaluation of extraction media and their suitability in a simple model to predict the biological relevance of heavy metal concentrations in contaminated soil. Int $\mathrm{J}$ Anal Chem 51:25-46

Gupta SK, Häni H (1989) Méthode pour la détermination dans les sols les concentrations de métaux lourds disponibles pour les plantes et les microorganismes et vérification dans les zones contaminées, Raport final COST 681, $\mathrm{Nr}$ 2. (FAC)

Hanson B, Werterberg L (2002) On correlation between heterozygosity and fitness in natural populations. Mol Ecol 11:2467-2474

Hanson B, Werterberg L (2008) Heterozygosity-fitness correlations within inbreeding classes: local or genome-wide effects? Conserv Genet 9:73-83

Hosius B, Bergmann F (1994) Adaptation of Norway spruce to heavymetal contaminated soils. In: Rone V (ed) Norway spruce provenances and breeding. Latvian Forest Research Institute "Silava", Riga, pp 200-207

ISO 11466 International Standard (1995) Soil quality — extraction of trace elements soluble in aqua regia, Geneva

Knowles P, Grant MC (1981) Genetic patterns associated with growth variability in ponderosa pine. Am J Bot 68:942-946

Korschikov II, Velikorydko TI, Butilskaya IA (2002) Genetic structure and variation in Pinus sylvestris L. populations degrading due to pollution-induced injury. Silvae Genet 51(2-3):45-49

Korshikov II, Ducci F, Terliga NS, Bychkov A, Gorlova M (2005) Allozyme variation of Pinus pallasiana Don. in Natural Crimean populations and in plantations in technogenously-polluted areas of the Ukraine steppes. Annals Forest Sci 61:389-396

Kurczyńska EU, Dmuchowski W, Włoch W, Bytnerowicz A (1998) The influence of air pollutants on needles and stems of Scots pine (Pinus sylvestris L.) trees. Environ Pollut 98(3):325-334

Lamppu J, Huttunen S (2003) Scots pine longevity and gradation of needle shedding along pollution gradients. Can J Forest Res 31(2): 261-267

Ledig FT, Guries RP, Bonefeld BA (1983) The relation of growth to heterozygosity in pitch pine. Evolution 37:1227-1238

Li B, Howe GT, Wu R (1998) Developmental factors responsible for heterosis in aspen hybrids (Populus tremuloides $x$ P. tremula). Tree Physiol 18:29-36 
Lis J, Piaseczna A (1995) Geochemical Atlas for Poland. PIG Warsaw, pp 1-74 (in Polish)

Longauer R, Gomory D, Paule L, Karnosky F, Mankovska B, MüllerStarck G, Percy K, Szaro R (2001) Selection effects of air pollution on gene pools of Norway spruce, European silver fir and European beech. Environ Pollut 115:405-411

Manly BFJ (1985) The statistics of natural selection on animal populations. Chapman and Hall, London, pp 272-282

Markert B (1994) Plant as biomonitors - potential advantages and problems. In: Adriano DC, Chen ZS, Yang SS (eds) Biogeochemistry of trace elements. Science and Technology Letters, Northwood

Markert B (1996) Instrumental element and multi-element analysis of plant samples - methods and applications, 2nd revised ed. Wiley, New York, p 296

Mičieta K, Murín G (1998) Tree species of genus Pinus suitable as bioindicators of polluted environment. Water Air Soil Poll 104: 413-422

Nelson DW, Sommers LE (1986) Total carbon, organic carbon and organic matter. In: Sparks DL (ed) Methods of soil analysis. Part 3. Chemical Methods. SSA Book Ser. 5. SSSA, Madison, pp 961-1010

Nieminen TM, Derome J, Saarsalmi A (2004) The applicability of needle chemistry for diagnosing heavy metal toxicity to trees. Water Air Soil Poll 157(1-4):269-279

Oleksyn J, Oleksynowa K, Kozłowska E, Rachwał L (1987) Mineral content and the sensitivity of black pine (Pinus nigra) of various provenances to industrial air pollution. Forest Ecol Manag 21:237-247

Pais I, Benton Jones J Jr (1997) The handbook of trace elements. Published by St. Lucie Press, 2000 Corporate Blvd. NW. 223 pp

Patra M, Bhowmikb N, Bandopadhyay B, Sharma A (2004) Comparison of mercury, lead and arsenic with respect to genotoxic effects on plant systems and the development of genetic tolerance. Environ Exp Bot 52:199-223

Patrice D (1998) Heterozygosity-fitness correlations: new perspective on old problems. Heredity 80:531-537

Pavlík M, Pavlíková D, Zemanová V, Hnilička F, Urbanová V, Száková J (2012) Trace elements present in airborne particulate matterstressors of plant metabolism. Ecotox Environ Safe 79:10-107

Peakall R, Smouse PE (2006) GENALEX 6: genetic analysis in Excell. Population genetic software for teaching and research. Mol Ecol Notes 6:288-295

Polish Standard (1994) Polish Standardisation Committee, ref. PrPN-ISO 10390 (E), Soil quality and pH determination. First edition (in Polish)

Prat S (1934) Die Erblichkeit der Resistenz gene Kupfer. Berichte der Deutschen Botanischen Gesellschaft 52:65-78

Prus-Głowacki W, Godzik ST (1991) Changes induced by zinc smelter pollution in the genetic structure of pine (Pinus sylvestris L.) seedling populations. Silv Genet 40:184-188
Prus-Głowacki W, Nowak-Bzowy R (1992) Genetic structure of naturally regenerating Scots pine population tolerant for high pollution near a zinc smelter. Water Air Soil Poll 62:249-259

Prus-Głowacki W, Chudzińska E, Wojnicka-Półtorak A, Kozacki L, Fagiewicz K (2006) Effects of heavy metal pollution on genetic variation and cytological disturbances in the Pinus sylvestris L. population. J Appl Genet 47(2):99-108

Puglisi S, Lovreglio R, Attolico M (1999) Subpopulation differentiation along elevational transects within two Italian populations of Scots Pine (Pinus sylvestris L.). Forest Genet 6(4):247-256

Rautio P, Huttunen S, Lamppu J (1998) Seasonal foliar chemistry of northern Scots pine under sulphur and heavy metal pollution. Chemosphere 37(2):271-278

Savolainen O, Hedrick P (1995) Heterozygosity and fitness: no association in Scots Pine. Genetics 140:755-766

Scaltsoyiannes A, Tsaktsira M, Pasagianni G, Tsoulpha P, Zhelev P, Iliev I, Rohr R (2008) Allozyme variation of the European Black (Pinus nigra Arn.) and Scots pine (Pinus sylvestris L.) populations and the implications on their evolution: a comparative study. Muzeul Olteniei Craiova. Oltenia. Studii si comunicari. Stiintele Naturii, Tom XXIV

Schaberg PG, DeHayes DH, Hawley GJ, Nijensohn SE (2008) Anthropogenic alterations of genetic diversity within tree populations: implications for forest ecosystem resilience. Forest Ecol Manag 256:855-862

Serbula SM, Miljikovic DD, Kovacevic RM, Ilic AA (2012) Assessment of airborne heavy metal pollution using plant parts and topsoil. Ecotox Environ Safe 76:209-216

Staszak J, Grulke NE, Marrett MJ, Prus-Głowacki W (2007) Isozyme markers associated with $\mathrm{O}_{3}$ tolerance indicate shift in genetic structure of ponderosa and Jeffrey pine in Sequoia National Park. California Environ Pollut 149:366-375

Stilwell KL, Wilbur HM, Werth CR, Taylor DR (2003) Heterozygote advantage in the American chestnut, Castanea dentata (Fagaceae). Am J Bot 90(2):207-213

Thomas GW (1982) Exchangeable cations. Methods of soil analysis, Part 2. Chemical and microbial properties (No 9), ASA-SSSA. Second Edition. Edited by Page A. L., Miller, R.H. and Keeney, D.R., Madison, Wisconsin, USA, 159-165

Vitalis R, Dawson K, Boursot P (2001) Interpretation of variation across marker loci as evidence of selection. Genetics 158:1811-1823

Yeh FC, Yang R-C, Boyle T, Ye Z-H, Mao JX (1997) POPGENE: the user-friendly shareware for population genetic analysis. Molecular Biology and Biotechnology Centre. University of Alberta, Canada

Ziehe M, Hattemer HH, Müller-Starck R, Müller-Starck G, (1999) Genetic structures as indicators for adaptation and adaptational potentials., in: Ma'tya's C (Ed.), Forest genetics and sustainability. Kluwer, Dordrecht: 75 